Г. Л. Кригер и др.; [отв. ред.: В. Н. Кудрявцев, А. М. Яковлев]. Москва: Наука, 1982. С. 205.

3. Панов М. І., Харитонов С. О. Суспільна небезпечність діяння в системі ознак поняття «кримінальне правопорушення». Проблеми законності. 2020. Вип. 150. С. 130-131.

4. Прозументов Л.М. Общественная опасность как основание криминализации (декриминализации) деяния. Вестник Воронежского института МВД России. 2009. № 4. С. 19.

5. Кудрявцев В.Н., Еминов В.Е. Криминология и проблемы криминализации. Журнал российского права. 2004. № 12. С. 103-107.

6. Наумов А. В. Российское уголовное право. Курс лекций: В 2 т. Т. 1: Общая часть. Москва. Юридиская литература. 2004. 496 с.

DOI https://doi.org/10.30525/978-9934-26-074-2-56

\title{
ВПРОВАДЖЕННЯ ПОЛОЖЕНЬ РИМСЬКОГО СТАТУТУ У ЗАКОНОДАВСТВО УКРАЇНИ - ПРАВОВИЙ ЗАСІБ ВИЗНАННЯ ЮРИСДИКЦІЇ МІЖНАРОДНОГО КРИМІНАЛЬНОГО СУДУ
}

\author{
Ситник В. А. \\ аспірант кафедри кримінального права № 1 \\ Начіонального юридичного університету імені Ярослава Мудрого
}

\section{Борисов В. I.}

доктор юридичних наук,

професор кафедри кримінального права № 1

Національного юридичного університету імені Ярослава Мудрого м. Харків, Україна

У 1998 році Генеральна Асамблея ООН скликала конференцію метою якої було утворення Міжнародного кримінального суду. 17 липня 1998 року було прийнято Римський статут, який вступив в силу 1 липня 2002 року після ратифікації 60 країнами, Цей нормативно-правовий акт став основою для заснування першого i постійно діючого кримінального суду.

Воєнні правопорушення $є$ найпоширенішою складовою основних міжнародних злочинів. Також слід зазначити, що воєнні злочини були визначені в нормах міжнародного гуманітарного права та регулю- 
вались низкою міжнародних документів ще до прийняття Римського Статуту. Найбільш застосованими документами у яких закріплена відповідальність за злочини є Женевські конвенції 1949 року про захист жертв війни та їх Додаткові протоколи що стосуються захисту жертв міжнародних збройних конфліктів та жертв збройних конфліктів не міжнародного характеру.

Стаття 8 Римського Статуту містить детальний перелік воєнних злочинів, на які розповсюджується юрисдикція Міжнародного кримінального суду, вчасності коли такі дії здійснені в рамках плану чи політики чи при широкомасштабному здійснені таких злочинів. Відповідно до цієї статті воєнними злочинами вважаються серйозні порушення Женевських конвенцій від 12 серпня 1949 року, а саме будь-які діяння проти осіб та їх власності, визначені у пп.і) - xxvi) п.а) ч. 2 ст. 8 Римського статуту. Однак важливо зазначити що ця стаття не відтворює всі воєнні злочини, закріплені в Додаткових протоколах. П.d ч. 2 ст. 75 Протоколу I передбачає заборону колективних покарань, ч.4 ст 51 Протоколу I передбачає заборону нападів невибіркового характеру. Серйозними порушеннями відповідно до п.с ч.4 Ст. 85 Розділу II Частини V Протоколу I визнаються діяння, застосування практики апартеїду та інших негуманних або знищуючих діянь, принижуючих особистість, що засновані на расовій дискримінації.

Такі серйозні порушення міжнародного гуманітарного права, як рабство та работоргівля в усіх іiі формах, заборона використовувати голод серед цивільного населення, як метод ведення воєнних дій передбачені у Статтях 4 та 14 Додаткового протоколу до Женевських конвенцій від 12 серпня 1949 року.

У випадку серйозних порушень норм міжнародного гуманітарного права, коли держави не в змозі або не належним чином переслідують осіб звинувачених у злочинах проти миру, безпеки людства та міжнародного правопорядку, Міжнародний кримінальний суд виступає додатковим механізмом здійснення правосуддя. Згідно з пунктом 2 статі 4 Римського статуту Міжнародний кримінальний суд може здійснювати свої функції і повноваження на території будь-якої держави-учасника, що передбачено Статутом та на території іншої держави на підставі спеціальної угоди. Україна не $\epsilon$ державою-учасницею Статуту, але $\epsilon$ його підписантом починаючи з 01.07.2002 року. На підставі двох заяв від уряду України Міжнародний кримінальний Суд може здійснювати юрисдикцію щодо злочинів, передбачених Римським Статутом і вчинених на території України, починаючи з 21 листопада 2013 року і далі.

Відповідно до ч.3 Ст. 12 Римського Статуту після визнання юрисдикції Міжнародного кримінального Суду на підставі заяв, держава- 
заявник здійснює співробітництво з Судом без затримання та виключень. Згідно з Частиною 9 Римського Статуту Україна проводить розслідування злочинів, що охоплені юрисдикцією Міжнародного кримінального Суду, здійснює кримінальне переслідування за ці злочини, забезпечує наявність правових процедур в національному праві для всіх форм співробітництва передбачених ч.9 ст. 93 Римського Статуту. На відміну від підписання, визнання юрисдикції на підставі заяв не надає державі-підписанту права мати представника в Асамблеї державучасниць, внесення правок до елементів злочину, приймати рекомендації для підготовчих комісій, та здійснювати інші функції, що сумісні 3 Римським Статутом або правилами процедури доказування [1].

Перша заява Верховної Ради України від 21.11.2013 року містить обмеження юрисдикції Міжнародного кримінального суду: часові розглядати порушення що відбувалися у період з 30 листопада 2013 року по 22 лютого 2015 року; географічні - м. Київ та інші міста України де проводилися мирні акції [5].

У другій заяві від 04.02.2015 року було зазначено, що Україна визнає юрисдикції суду стосовно злочинів проти людства та військових злочинів передбачених статтями 7 і 8 Римського Статуту, вчинених починаючи з 20 лютого 2014 року і по сьогодні, тим самим продовжуючи часові рамки юрисдикції Суду на території України [6].

Ратифікація Римського Статуту Міжнародного кримінального суду до Кримінального кодексу України дозволить розслідувати серйозні міжнародні злочини без заяв уряду про вчинення таких злочинів. Ратифікуючи Статут держава може набути прав учасника, що дозволить не лише виконувати запити про співпрацю, а й брати участь у формуванні, діяльності та подальшому розвитку Міжнародного кримінального суду.

\section{Література:}

1. Rome Statute of the International Criminal Court [Електронний pecypc] : [Веб сайт]. - https://www.icc-cpi.int/resourcelibrary/officialjournal/rome-statute.aspx_(дата звернення: 10.03.2021)

2. The Prosecutor of the International Criminal Court, Fatou Bensouda, issues her annual Report on Preliminary Examination Activities (2019) [Електронний pecypc] : [Веб сайт]. - https://www.icc-cpi.int/items Documents/2019-PE-Report-UKR.pdf_(дата звернення: 05.02.2021)

3. Єдиний звіт про кримінальні правопорушення за січень-вересень 2020 року // Офіс Генерального прокурора [Електронний ресурс] : [Веб сайт] https://www.gp.gov.ua/ua/stat_n_st? $\mathrm{m}=$ fslib\&_t=fsfile\&_c=download \&file_id=209818_(дата звернення: 20.01 .2021 ) 
4. Кримінальний Кодекс України: станом на 05.01.2017 р. / Верховна Рада України // Офіційний вісник України 2001, 21 від 08.06.2001. Ст. 920.

5. Заява Верховної Ради України до Міжнародного кримінального суду «про визнання Україною юрисдикції міжнародного кримінального суду щодо скоєння злочинів проти людяності вищими посадовими особами держави, які призвели до особливо тяжких наслідків та масового вбивства українських громадян під час мирних акцій протестів у період з 21 листопада 2013 року по 22 лютого 2014 року» [Електронний ресурс]: [Веб сайт] https://zakon.rada.gov.ua/laws/show/790-18\#Text (дата звернення: 12.03.2021)

6. Заява Верховної Ради України до Міжнародного кримінального суду «Про визнання Україною юрисдикції Міжнародного кримінального суду щодо скоєння злочинів проти людяності та воєнних злочинів вищими посадовими особами Російської Федерації та керівниками терористичних організацій «ДНР» та «ЛНР», які призвели до особливо тяжких наслідків та масового вбивства українських громадян» [Електронний ресурс] : [Веб сайт] https://zakon.rada.gov.ua/laws/show/14519\#Text (дата звернення: 12.03.2021)

DOI https://doi.org/10.30525/978-9934-26-074-2-57

\title{
СЛУЖБОВІ ЗЛОВЖИВАННЯ У СТРУКТУРІ КОРУПЦІЙНИХ КРИМІНАЛЬНИХ ПРАВОПОРУШЕНЬ
}

\author{
Харченко В. Б. \\ доктор юридичних наук, професор, \\ завідувач кафедри кримінального права та кримінологіі \\ факультету № 6 \\ Харківського начіонального університету внутрішніх справ \\ м. Харків, Україна
}

Зміна пріоритетів у відносинах держави та особи, переорієнтація ставлення до особи як до вищої соціальної цінності й потреба у перетворенні України на «державу для людини» викликали необхідність розглядати органи державної влади та органи місцевого самоврядування, їх посадових осіб, з одного боку, як таких, що перебувають на службі у суспільства, а з іншого - як гарантів забезпечення охорони прав і свобод людини та громадянина, власності, громадського порядку й громадської безпеки, довкілля, конституційного устрою України від зло- 